\title{
Present Situation Analysis and Countermeasure Research of Human Resource Management and Development in Colleges and Universities
}

\author{
Yanqing Zeng \\ Xi'an Fanyi University, 710105 Xi'an China \\ 75700789@qq.com
}

\begin{abstract}
Keywords: High efficiency; Human resources; Management development; Methods and Countermeasures
\end{abstract}

\begin{abstract}
The development of the times promoting the progress of science and technology, science and technology level has become the main factors to measure the level of productivity, to achieve the development of society, we must conduct a reasonable human resource management process. Colleges and universities are the most concentrated place of talent, the development of colleges and universities should strengthen the establishment of the talent reserve and effective incentive mechanism, so as to attract talent, the use of talent. this paper, the latest modern human resource management theory as a theoretical guide, Through the analysis of the current situation of human resources management in Colleges and universities in china, Effectively put forward the solution of the contradictions in the human resources in Colleges and universities in the views and suggestions, And thus provide effective help for the human resource management department.
\end{abstract}

\section{The Characteristics and Management of Human Resources in Colleges and Universities}

The Meaning and Characteristics of Human Resource. Human resources refer to the individual ability to effectively promote the development of the economy and society, that is, the process of using personal physical and mental processes in the process of production and labor. Human resources usually include people's knowledge, ability, intelligence and physique, and so on. Our country's human resources have the following characteristics: first, the human resources have the biological nature. In human resources and natural environment, people are living organisms, is living resources, which is determined by the nature of human nature. Secondly, human resources have the initiative.

Man is different from other creatures, who has a personal subjective thought, emotion, can engage in meaningful, purposeful activities, can actively carry out the transformation of the objective world. The main performance of human resources initiative is as follows: the strengthening of the self, the choice of the occupation and the positive work of the individual.

The Composition of Human Resources in Colleges and Universities. Human resources in Colleges and universities covers a very wide range, and the management of human resources is the main body of human resources. Human resources in Colleges and universities mainly include four contents: in particular, the personnel engaged in scientific research, the staff in the party and government management, the staff in the logistics service and the retired staff. In the process of human resources management, effectively around the aim of running a school, according to the characteristics of all staff and the human resources of colleges and universities for the overall development, to effectively improve the quality and efficiency of school is important and worthy of consideration.

Characteristics of human resources in Colleges and Universities. The distribution of human resources in Colleges and universities is highly concentrated. Colleges and universities are highly concentrated areas of talent resources, therefore, in the number and distribution of personnel resources intensive, talent concentration is far higher than other occupations.

The overall level of the quality of human resources in Colleges and universities is very high. Colleges and universities are the cradle of culture is the cradle of knowledge, is the birthplace of 
knowledge learning and innovation, the various disciplines of talent gathered in Colleges and universities. It can be said that the university has a high talent reserve.

Human resources in Colleges and universities are full of vigor and vitality. Colleges and universities have a large number of specialized talents and professional intellectuals, in the face of the increasing scarcity of talent resources and the growing demand for talent. Colleges and universities need to cultivate more and more complex talents, so as to meet the needs of the development of the times.

The composition of human resources in Colleges and universities has a wide range of characteristics. The human resources in Colleges and universities consists of members of the teaching and research staff, party and government organs logistics service staff and school run industries, from retired staff. Therefore, the background of the talents in Colleges and universities has diversified characteristics.

\section{Characteristics and Analysis of the Development and Management of Human Resources in Colleges and Universities}

The Development and Management of Human Resources in Colleges and Universities Lies in the Knowledge Itself. In today's era of knowledge economy, the knowledge economy is the intellectual economy, which is the economy of the possession, distribution and use of knowledge. Universities as the cradle of the cultivation of senior intellectuals, the key to improve the efficiency of the production of knowledge, that is, the production of knowledge and knowledge into technology and product efficiency. The productivity of university knowledge depends on the development and utilization of knowledge. Therefore, the process of human resource management in modern colleges and universities is mainly from the traditional management of human to the management and development of knowledge.

The Development and Management of Human Resources in Colleges and Universities Lies In the Innovation Of Mechanism. University human resources management should pay attention to the development and innovation of the system, through the use of the system, distribution mechanism, evaluation and other aspects of the establishment of perfect competition, incentives, such as the elimination of the new mechanism to effectively promote the development and management of human resources in Colleges and universities.In the talent of reference, stability, and other aspects of human resources structure adjustment, the design of human resource allocation, we should be good at innovation, determined to reform.In order to achieve the stability of the talent team, the construction and management of high quality human resources team, it is conducive to the initiative and enthusiasm of the work of encouraging talents, through the efficient transformation of various results, to enhance the connotation construction of higher education and to improve the vitality and efficiency of running a school, the effective implementation of higher education policy and academic ideas.

The Development and Management of Human Resources in Colleges and Universities should Serve the Purpose of Learning. Colleges and universities in the entire school teaching system are at the top, which is the inheritance of tradition; carry forward the knowledge of the senior hall. It can be said that the logical starting point of the University from the academic excellence, all of the colleges and universities are so. Academic level is the fundamental of the University, for the academic management is the reason for the existence of the university. With the expansion of College enrollment, the process of teaching and learning should be adapted to the economic and social development. In the development process of human resource management, should develop in a scientific and efficient way. At present, the development and application of human resource management should be subject to the center of academic management.

The Development and Management of Human Resources in Colleges and Universities should Be Considered from the Strategic Point of View. The development and management of human resources in Colleges and universities is not only the responsibility of the personnel department, but also the responsibilities of the staff and the manager. University teaching managers 
need to assume the responsibility for the management of the school staff, pay attention to the teacher's personal growth and career development, and through the establishment of policies and systems to ensure that. At present, the management of human resources in Colleges and universities in China is divided into three parts: First of all, the human resources management of the functional departments in Colleges and universities. Secondly, colleges middle-level performance work; Thirdly, the self-management and value development of teaching staff in Colleges and universities. In the work of human resource management and development, the university should pay attention to the transformation from administrative power to service, to dilute the management of talents, and to enhance the staff's requirements and management of self.

\section{The Current Situation Analysis of Human Resource Management in Colleges and Universities}

Lack of Effective Control in the Human Resources Management of Universities in China. China's colleges and universities in the process of human resource management, the lack of effective regulation and control policy, leads to the existence of human resources in China's colleges and universities, the phenomenon of uneven. Our universities are mostly concentrated in the eastern region and the economic development of the region, which makes China's eastern coastal areas and Beijing, Guangzhou, Shanghai and other cities have become a talent intensive area. Concentration of talent in developed areas are too much, but less developed areas with economic backwardness and the scarcity of talent gathering. This not only affects our country to implement the strategy of developing the country through science and education, but also caused the University in the human resources management work is difficult to play the best effect.

The Lack of Proper Resources in Human Resource Management in China's Colleges and Universities. Chinese universitieslack proper human resource management and resource allocation in. Currently, subject to the restrictions of objective conditions, many colleges and universities in our country did not really establish a scientific and rational personnel management mechanism and the management of the University stay in the era of planned economy. In addition, the deviation of the ideological concept, leads to the lack of the importance of human resource allocation in some college teaching managers, results in a very low efficiency and lack of rationality in human resources management and resource allocation.

The Lack of Sustainable Mechanism in Human Resource Management in China's Universities. There is a general lack of the system of human resource management in Colleges and universities in China, which has not formed a long-term development plan in the personnel management work. Universities themselves in teaching and management due to the government and related departments of the institutional constraints, between the various functional departments have not yet formed a highly efficient and close contact, which leads to the dispersion of human resources. In the macro policy, the system of human resource management and development in Colleges and universities is not perfect; At the micro level, The education management of higher education in our country and the relevant laws and policies are not perfect. A large amount of investment in education funds has not received a good return, instead, resulting in a waste of resources and waste of funds. At the same time, due to the lack of effective human resources planning, the talent pool is not balanced, it is difficult to meet the construction and development of the university itself. Universities to realize their own scientific expansion, we must increase the introduction of talent and incentive system, otherwise it will seriously affect the level and structure of human resources.

\section{The University Human Resources Management Problems Countermeasures}

Our Country Colleges and Universities Should Establish and Perfect the Effective Talent Competition Mechanism. China's colleges and universities to establish a scientific and rational talent competition and reward mechanism, through the contribution of the size and value of talent, determine its reward and incentive system. The use of scientific competition system to stimulate the work of the human desire and its own requirements, Is the talent in the work process can better play 
the value and potential. In Colleges and universities of our country human resource management needs to introduce competition mechanism, realizing to talented person's survival of the fittest. The competition in science to achieve personnel own quality is improved, and the human resources team in a healthy and stable state, helps to realize the healthy and orderly development of the industry. At the same time, in order to establish and perfect the mechanism of talent competition, universities should follow the open, just and fair ideas, scientific selection of talents, correctly evaluate of the value contribution of talent, according to its working performance and the ability to determine the actual job responsibilities, make use of the expertise and resources. At the same time, the establishment of a sound talent competition system also includes evaluation system and mechanism, therefore, colleges and universities to establish a scientific and objective evaluation criteria and regular staff to implement the assessment. In the operation process, should pay attention to the operation of the normative, ensure the assessment of transparent, objective, and determine the only assessment criteria and the long-term implementation.

China's Colleges and Universities Should Fully Do a Good Job on the Sustainable Development of Personnel Planning. Along with the development of the times and the progress of the society, higher requirements for talents in Colleges and universities in chinain the fierce competition, colleges and universities for its development and in position, managers need to have the foresight consciousness, to make advanced forecast and planning, the work of human resource management. The administrative management of colleges and universities should combine the national conditions of our country and the actual situation of the school itself, to design a scientific and reasonable human resource management and development planning, with the vision of scientific development as the guiding ideology, and to establish a high quality teaching staff, which aims to cultivate talents and absorb talents. At the same time, college and universities in the construction process but also cultivate a sense of reserve talents, organize regular faculty, staff and administration to participate in the training and education, for talent development and further enhance to create favorable conditions, and let talent under the guidance of new ideas and concepts to better engage in the work, to achieve the sustainable development of colleges and universities.

Universities in China Would Build a Combination of Human Resources Management and Teaching Staff. The development and growth of the school depends on the ability of the part-time teachers and managers, it can be said that the quality of the management of colleges and universities in our country determines the level of school management and effectiveness. Universities in our country should cultivate and improve the quality and level of managers, and build a team of human resources management. In the process of selecting and employing people, attention from the knowledge, ability, character, culture and other aspects of multi angle, effectively improve the management of the theoretical level and practical ability, Change in the management of the old ideas and methods of work, set up the correct education teaching work idea which conforms to the time request, to realize the integration of colleges and universities and the development of the times.

In The Human Resources Management in Universities in Our Country to Establish a People-Oriented Concept. China's colleges and universities in the human resources management should focus on people-oriented, which are in line with the economic and social development needs, but also in line with the development of their own. Twenty-first Centuries is a highly competitive society, in order to do the characteristics of the higher education, we must follow the laws of the market. Only by changing the old management methods and ideas, can establish a people-oriented management philosophy, can achieve the effective combination of higher education and market economy. The higher education in our country should be based on the interests of the educators and the talents, to achieve "people-oriented, talent first" concept, establish and improve various management mechanisms, to achieve a teacher centered management system, in fact, to solve the problem of sustainable development of college education and personnel. The higher education in our country should be based on the interests of the educators and the talents, to achieve "people-oriented, talent first" concept, establish and improve various management mechanisms, to achieve a teacher centered management system, in fact, to solve the problem of sustainable development of college education and personnel. At the same time, our country should have the 
consciousness of the education and teaching of talents and life to establish a harmonious and stable academic environment, using the personnel department of the University and the function of the management department, to provide a solid support for the education of the college logistics service, So as to create a human resource management model in line with its own characteristics, according to this to attract top talent and retain talent, stimulate talent, faculty, staff, and all kinds of talented persons are willing to give advice to the development of colleges and universities to contribute.

\section{References}

[1] Xu Xunfeng. The current situation and Countermeasures of human resource management in Colleges and universities in China [J].College logistics research, 2011 (01)

[2] Wang Junfeng, Zhang Jianhua. Research on the problems and solutions in the development and management of human resources in Colleges and universities [J].Journal of social science, Jiamusi University, 2014 (04).

[3] Fu Qingye. Problems and Countermeasures of human resources management in Colleges and universities in the minority areas in the border areas $[\mathrm{J}]$. Coastal enterprises and science and technology.2005, (4): 28

[4] Shang. Shihai" Learning oriented colleges and universities" and its establishment [J].Liaoning education research.2003, (1).

[5] Liu Xifa. Research on the current situation and Countermeasures of human resources development in Colleges and universities [J].Research on the Countermeasures of.2008, (19).

[6] Zhang Xiaobing, Xin. Problems and Countermeasures in the development and management of human resources in Colleges and universities (J).Research on continuing education.2009, (8).

[7] Liao Quanwen. Human resource management [M]. Shanghai: Tongji University press, 1991

[8] Wang Wei. Research on human resource management and development strategies in Universities [J].adult education, 2007, (1).

[9] Huang Yuzhen. Research on the reform strategy of human resource development and management in Colleges and universities [J]. Heilongjiang high education research, 2006, (12)

[10]Zhao Puguang. university human resource management based on the strategy [J], Longjiang higher education research, 2007, (2).

[11]Tang Zhongyang. The contradictions and Countermeasures in the introduction of talents in Colleges and universities [J].modern university education 2002, (4).

[12]Jiang Renliang. Research on the reasonable development and scientific management of human resources in Colleges and universities [J].Education theory and practice, 2005, (20). 